\title{
Togetherness in the Diversity of the Pancasila Ideology Frame
}

\author{
Syukri Hamzah \\ Universitas Bengkulu, Indonesia \\ e-mail: eshanursal@gmail.com \\ Mohd Hilmy Baihaqy Yussof \\ Kolej Universiti Perguruan Ugama Seri Begawan, Brunei Darussalam \\ e-mail: baihaqy.yussof@kupu-sb.edu.bn \\ Alexis Arizabal-Enriquez \\ State Institute of Sciences and Technology Bangued Campus Bangued, Abra, Philippines \\ e-mail: enriquez@asist.edu.ph
}

Article History: Received on 14 July 2020, Revised on 18 July 2020, Published on 27 July 2020

\begin{abstract}
Every nation that has been national ideology applied in it is guidance and a guideline in every action of the state and the citizens of that state. Each ideology has a distinctive way of thinking, so the goal of achieving the nation's goals must remain in that way of thinking it belongs. Thus, the way of thinking Pancasila as an ideology of the Indonesian citizen and state became a need as inevitable as a guideline for how to think in acting and doing in the context of the interests of the nation and country, not using other ideologies.
\end{abstract}

Keywords: Pancasila; Ideology; Togetherness; Diversity

\section{A. Introduction}

Since the reform of 1998, the reality on the reverent Pancasila had vanished and stunted the earthquake of the reforms that wanted a better condition of the previous condition that had been considered less popular. The attributes of Pancasila in various areas of life seemed to be involved with the hopes manifested in the attributes of democracy, transparencies, human rights, and many others. The Pancasila seemed to belong to the previous order of governance. The position of Pancasila is formal as the basis of the country as it is ruled out by various things related to the developmental phenomenon that occurred in the society at that time and still occurs today. Furthermore, the position and function of Pancasila as the ideology or philosophy of life of the nation seems to have been forgotten in many activities of nations and states, as well.

On the other hand, a community that has entered the era of advanced technology might have taken effect on the conditions that were stated above. Technology that is originally a system that facilitates gradually tends to be a force that determines the behavior and patterns of people's lives. Today's public condition is more referring to the concrete range that has denied the things of a philosophical concept instantly. Public awareness on Pancasila as an ideology has been increasingly terrified of by these developmental conditions, although in the state and in the nation, it still refers the very basic Pancasila. However, the individualist is a group of people who were more driving than delving on the attitude of togetherness. Besides, the Sara -smelling and horizontal conflict issues that are constantly being triggered by a group of 
people today in the sidelines of the nation has been quite alarming. "We or we" should be a serious problem for all of the nation's children if we do not want "Indonesia" to be the name of a nation and a country that has existed in history.

The question that arises "not Pancasila is no longer a reference in the life of the nation and state?" must be answered together. An association that is a brief explanation is trying to discuss the diversity of the nationality that framed the ideology of Pancasila, an "ideology" in the life of Indonesia and the Nation itself.

\section{B. Nation and Nationality}

The sense of the nation according to Bachtiar (1987) is a unity of great solidarity, created by the feelings of sacrifice that had been made in the past and which the people in question were willing to make in the future. Nasion had the past, but continued to be in the present day through a clear reality; That is a deal, a real desire to continue to live together". Therefore, according to Bachtiar (1987), a nation does not depend on the similarity of race, ethnic origin, religion, language, geography, or other similar things, but is bound by a common goal and a sense of sensible, as well as a struggle.

Thus, if we speak of Indonesian national, certainly no longer based on birth, ethnic origin, or race of origin, but based on the feeling of Indonesian nationality who wants to live together in a region where the nation is alive. Indonesian National is a new social unity that has a bond of solidarity that covers all of its members. A National, who, is no longer with its own culture and identity, but a nation with language, culture, and values, and the sole identity of the nation itself. On that basis, we must be able to accept the reality as it is that the nation of Indonesia is a compound nation that is tied to a solid by common sense and ideals. This condition also confirms that "diversity" is one of the characteristics inherent to the National of Indonesia. In the later stages, this Indonesian National formed a country named Indonesia with a joint national ideal which is stated in the opening of the Indonesian constitution, known as the Constitution 1945. Thus, every member of National Indonesia has the same rights and obligations in life and a life in the homeland of Indonesia and must strive together to achieve these common ideals.

Understanding the conditions expressed on the face may lead us to understand that the condition of the people and all the peoples of Indonesia correctly and sincerely, both socially and psychologically. The nations described above do not necessarily deny the original condition of any individual national. Local cultures will still color the attitudes and behaviors of each individual with their own place. It is not an obstacle realizing the mutually agreed goals. Thus, the same cultural values will be preserved in the form of a national culture that binds the senses of unity and togetherness of an individual in a nation that has been repressed.

Therefore, Indonesia sees a new nation that has the guidance of life and an attitude as a reference of Life of the society- a Nation and a State that is in a mutual agreement that is believed to be true. Thus, National Indonesia gave the reference name with Pancasila, born from cultural values that lived, flourished, and maintained in Indonesian society. Therefore, it can be said that Pancasila is the crystallization of the cultural values of Indonesian peoples themselves. As the core of Indonesian cultural values, Pancasila can be referred to as the moral ideals of the Indonesia as a Nation. These moral ideas then give guidance, grip, or spiritual power to the nation of Indonesia in the Life of society, nation, and state. In other 
words, every move or idea that comes up should always be imbued by Pancasila. Furthermore, this joint reference is known as the ideology that became the basis for the establishment of Indonesia.

\section{The Nature of Pancasila ideology}

The notion of ideology was introduced by thinkers in the late 18th century. But the following explanation will only convey the ideological understanding that is following the context of our discussion, namely the ideology of Pancasila. The ideology according to Poespowardojo (1989) is the overall principle or norm prevailing in a society that encompasses various aspects, such as social-political, economic, cultural, and Hankam. Ideology is a whole principle and norm or motivation to act. Oesman and Alfian (1992) suggest that the ideology is indicative of a comprehensive and profound set of fundamental values or systems that are owned and held by citizens or nations as their insights and views of life. According to Patrick Cobert as cited by the Great (1990) ideological formulation that has not yet contained the value is as follows:

Each psychiatric structure is composed of namely: 1) a set of beliefs about organizing the lives of people and their organization; 2) a set of beliefs about the nature of man and the universe living therein; 3) the declaration of incorporation that both statements of belief are intertwined; and 4) be confident that the beliefs are considered and the belief is recognized as truth by all persons who are full members and social groups concerned.

Thus, it is an essential ideology that commences from the view and beliefs of a group of people who made references or guidelines for codes of behavior. Thus, ideology has the peculiarities inherent in the ideology. Its implementation always refers to the values contained in the ideology although the way of execution differs.

As for the characteristics of the ideology according to Great (1988) includes the following1) ideology is an expression of the conscience of the public about the ideal words that are being hardened and thorough; 2) the ideology is wide-blown; 3) ideology always has its logic following his views on the universe; 4) ideology must contain a distinctive method to realize a distinctive dream; 5) ideology is a systematic pattern of political thought; 6) ideology contains empiric or normative elements that are each poured in the formulation of philosophy; and 7) ideology is always distinctive and universal.

More on the function inherent to an ideology is in the following positions namely: 1) as a device of understanding; 2) Ideological presenting patterns of leads; 3) raising unity; 4) set goals; 5) get a social consensus; and 6) guiding the process of embodiment objectives.

A brief description of the ideology and characteristics expressed above brings us to the understanding that ideology is nothing but an insight (perspective), a view of life or a national philosophy typical for a nation. In the ideology contained the knowledge and complex values that overall will be the foundation in understanding the universe and the earth of its contents and determine the basic attitude to process it. Therefore, with his ideology, a strong nation will answer the challenges of his day and will be the foundation and purpose of acting, life, nation, and state in various dimensions. 
As expressed by Gollnick and Chinn (2011) that culture determines who we are, Pancasila as an ideology of the nation and the state of Indonesia is formulated from the culture of Indonesia gives color to critical thinking, action, and behavior of Indonesia as a Nation. Culture affects our knowledge, beliefs, and values. It gives a blueprint that determines the way we think, feel, and behave. A generally and patterned way of behavior is required for a group of people to live together, and culture imposes regularity and meaning on our experience. Thus, it can be said that Pancasila is a religion that is embraced by the state as a nation.

\section{Implementation of Pancasila Ideology In Diversity and Togetherness}

Referring to the description expressed earlier, Pancasila as the ideology of the nation and state of Indonesia has its characteristics and special methods in carrying out its functions against the nation and state of this country. This means that the way of thinking and the method of Pancasila is not the same as the method of ideological thinking. In other words, the ideals that are contained in the ideology of Pancasila can only be realized only when the talents use a method of thinking that is typical of Pancasila ideology. If the method of thinking uses other ideology, although the creators intend purely to realize the ideals contained in the ideology of Pancasila but manifest it differently does not conform to the ideals of Pancasila ideology.

Pancasila, which is contained in the opening of the constitution 1945 which is also an ideology of Indonesia that contains the Instrinsik ideals. Its method of action, and the size of its truthfulness that is morally binding and guiding all the components of the nation in acting and doing to realize the ideals of a national independence. A set of Instrinsik values in the Pancasila is intertwined with the action that makes up a whole. Therefore, Pancasila ideology was also a character of the integralists. The logical consequence is that integralists' thinking is an inevitable necessity if we want to manifest the Pancasila into a reality of the attitude of a society, nation, and state. Thus, all policies and actions to realize the benefits and ideals of the nation must be based on a way of thinking integralists that is characteristic of the method of thinking of Pancasila ideology.

Based on the typical way of thinking of Pancasila, then its implementation in national and state life can be identified into some of the following control signs 1) decision-making policy should still uphold the value and dignity of human beings while maintaining the ability to adapt the community to the policy; 2) the ideology of Pancasila must be made a foundation in determining the feasibility of a program or policy so that it does not contradict the values contained in Pancasila; 3) the direction of development and development of the community must always be guided by the control of Pancasila ideology to strengthen the unity and the nation; 4) things contrary to the ideology of Pancasila must be abandoned; 5) the policies and programs that are executed must lead to the realization of the welfare and prosperity of the entire nation; and 6) Pancasila is the ideology of the nation is a mutual agreement that is born from the diversity of conditions and background of all elements of the nation.

Thus, based on the previous abridged explanation we can declare that Pancasila is the most suitable reference in the life of the Indonesian nation that has been said because Pancasila was born from the cultural values of the nation that has given a very large and definite space. 


\section{E. Conclusion}

The brief exposure above shows that togetherness with diversity has become the undisputed characteristic of the Indonesian nation-state. Differences in cultural, ethnic, and religious matters do not need to be debated but must be accepted as an invaluable gift. The prosperity will be insight the wealth of nations that will be a source of the nation's progress. Besides, that needs to get our attention that every ideology has a distinctive way of thinking about the ideology itself. Pancasila as an ideology of the nation brings the inevitable consequence of the necessity that the Pancasila should be the foundation and the framework of the nation's thinking in organizing, developing, and maintaining every step of the nation's movements. Pancasila must be a method of solving problems in national and state life. By adhering to Pancasila as an ideology, we will be able to overcome the dynamics and phenomenon of internal problems of nations and among the nations. Deviations against Pancasila ideology, regardless of the shape and form is ensured of unrealized ideals of independence of the nation and state of Indonesia. Hopefully, it's a little bit of this description though there's a slight benefit for all of us. Lastly, allow me to share to everyone this useful quotation, "forget the vain".

\section{F. Acknowledgement}

We would like to express our special thanks and gratitude to Rector Universitas Bengkulu, Indonesia, Kolej Universiti Perguruan Ugama Seri Begawan, Brunei Darussalam and Abra State Institute of Sciences and Technology Bangued Campus Bangued, Abra, Philippines who gave us the support to do this wonderful project. This project was funded independently. Secondly, we would also like to thank our friends who helped us a lot in finalizing this project within the limited time frame.

\section{REFERENCE}

Bahctiar, H. W. (1987). National Insight. Jakarta: BAKOM-PKB Center.

Great, A. K. (1988). Thinking Integralists. Jakarta: Lemhannas.

Gollnick, D. M., Chinn, P. C. (2017). Multicultural Education In A pluralistic Society. Boston: Pearson.

Hamzah, S. (1992). The direction of the ideology of Pancasila in technology utilization to realize the goals of National.

Hamzah, S. 1994. Urgensi Perkuliahan Filsafat Pancasila di Perguruan Tinggi [Urgency Philosophy of Pancasila in Higher Education]. Harian Semarak, August 1994

Oesman, O., \& Alfian. (1992). Pancasila Sebagai Ideologi [Pancalisa as an Ideology]. Jakarta: BP-7 Pusat.

Poespowardojo, S. (1989). Filsafat Pancasila: Sebuah Pendekatan Sosio-Budaya [Philosophy of Pancalisa: Socio Culture Approach]. Jakarta: Penerbit PT Gramedia. 